\title{
Water Quality Measurements with a Simple Molecular Analysis (PCR- RFLP) of the Microbiome in a Metropolitan River System in Japan
}

\author{
Liswara NENENG ${ }^{1, \dagger}$, Rudy Agung NUGROHO ${ }^{2, \dagger}$, Yukio KOMAI ${ }^{3}$, \\ Naru TAKAYAMA ${ }^{3}$ and Koji KAWAMURA ${ }^{3, *}$ \\ ${ }^{1}$ Department of Biology Education, University of Palangka Raya, Indonesia \\ ${ }^{2}$ Animal Physiology, Development, and Molecular Laboratory, Department of Biology, \\ Faculty of Mathematics and Natural Sciences, University of Mulawarman, Indonesia \\ ${ }^{3}$ Department of Environmental Engineering, Osaka Institute of Technology, Japan
}

('Corresponding author's e-mail: koji.kawamura@oit.ac.jp)

Received: 16 July 2018, Revised: 21 July 2019, Accepted: 23 August 2019

\begin{abstract}
Urbanization has affected natural freshwater environments by contamination with sewage, toxic chemicals, and excess nutrients, which cause algal bloom, pollution, and ecosystem degradation. To ensure sustainable use of natural waters, appropriate monitoring methods are required. This study aims to investigate the diversity of the microbial community in a metropolitan river system in Japan using a lowcost DNA-based approach, PCR (Polymerase Chain Reaction)-RFLP (Restriction Fragment Length Polymorphism), as a potential bioindicator of environmental change. Surface waters were sampled in seven sites in a river system. Water chemical parameters and concentrations of heavy metals were determined. Microbial DNA was extracted from the samples, ribosomal RNA was amplified with universal primers, and RFLP was scored by agarose gels. Water chemical analyses showed that surface water at the inflow point of a sewage treatment plant had signs of eutrophication. Heavy metal concentrations in surface water were low $(<0.01 \mathrm{ppm})$ in all sites. The PCR-RFLP analysis showed polymorphisms both in $16 \mathrm{~S}$ and $18 \mathrm{~S}$ rRNAs, indicating that the method can detect at least a part of the microbiome changes in a river system. Sequencing of some fragments found the sequence close to a ciliate isolated in wastewater treatment plants, implying contamination from sewage. Principal component analysis (PCA) identified the RFLPs associated with chemical water parameters, which could be bioindicators of environmental pollution. We also found the RFLPs independent of water quality parameters, suggesting that this simple DNA-based analysis can also detect biological changes in water ecosystems that are not quantified by chemical measurements of water quality.
\end{abstract}

Keywords: Freshwater environment, ribosomal RNA, principal component analysis, water chemistry

\section{Introduction}

Natural freshwaters such as lakes, rivers, and streams in cities are important places for cleaning wastewater and urban sewage, buffering heavy rainfall, and human recreation. They are also the main sources of drinking water in many countries. Increasing human population and urbanization has affected natural freshwater environments by contamination with sewage, toxic chemicals, excess nutrients, and the construction of river walls, which cause harmful algal bloom, environmental pollution, and ecosystem degradation [1] and hamper the use of natural freshwater environments for human consumption and

\footnotetext{
${ }^{\dagger}$ The first and the second authors contributed equally
} 
http://wjst.wu.ac.th

recreational activities in cities. To ensure sustainable use of natural freshwater environments in cities, appropriate monitoring methods and systems are required to identify signs of environmental deterioration in advance.

Microorganisms in freshwater environments in cities play critical roles in the biogeochemical cycling of organic matter and nutrients, the maintenance of ecosystem health, and the biodegradation and transformation of pollutants [2,3]. The diversity and community structure of microorganisms in water can change in response to physicochemical and biotic parameters and, thus, can be used as indicators of environmental changes [4-9]. Biomonitoring using indicator species of macroinvertebrates in water has been widely used in water management practices to infer water quality and ecosystem health status $[10,11]$. In addition, the effects of urban human activity on freshwater environments have been intensively studied using physicochemical parameters, such as nutrients [12] and heavy metals [13], but has been less explored by microbial community analyses [7]. In particular, previous studies on microbiome responses to anthropogenic disturbances have focused on oceans and lakes, and only a few studies have been conducted in rivers and groundwaters [14].

Microbial community analyses have long been dependent on culture-based methods, where the methods have been biased in the evaluation of microbial diversity because only a small percentage of microorganisms can grow in artificial cultures. With recent advances in genomics and sequencing technologies, microbial community analyses using culture-independent molecular techniques have initiated a new era of microbial ecology $[15,16]$. Although the molecular techniques provide detailed information of microbiomes on the basis of diversity of DNA sequences, they need relatively expensive reagents and facilities for molecular biological experiments. This hampers the wider use of the DNAbased analysis of microbiomes.

This study investigated the diversity of the microbial community in a metropolitan river system in Japan based on a low-cost and simple DNA-based approach, namely the PCR-RFLP (Polymerase Chain Reaction-Restriction Fragment Length Polymorphism) method. The method is based on the PCR amplification of ribosomal RNA with universal primers and the subsequent fragmentation of the amplified DNA by restriction enzyme digestion. Restriction enzymes have specific nucleotide sequence recognition sites and cut the DNA at those sites. Variation in the sequence at those recognition sites in the amplified DNA fragment results in different size fragments among taxa. The banding pattern, i.e., distribution of fragment lengths can, therefore, change in relation to changes in microbiomes. This technique is relatively inexpensive and requires only basic and widely available molecular laboratory equipment [15]. The PCR-RFLP method does not provide any sequence information, in contrast to the cloning and sequencing approach, but the fragments separated in an agarose gel can be sequenced individually, which provides the chance to identify indicator species of environmental change.

We, therefore, adopted the PCR-RFLP method to assess microbial community changes in a metropolitan river system in Japan. Simultaneously, we made physicochemical measurements of water quality and examined correlations of microbial community changes with water quality parameters using principal component analysis (PCA). Based on the results, we discuss the potential of the PCR-RFLP analysis of microbial community changes as a bioindicator of natural water environmental changes in cities.

\section{Materials and methods}

\section{Study sites and sample collection}

The study site is the Yodo river system in metropolitan Osaka, Japan (Figure 1). The river system originates from three main rivers (the Katsura river, the Uji river, and the Kizu river), one of which comes from Lake Biwa, and flows into Osaka Bay. The river system is located in the largest city area in western Japan, including Kyoto (1.5 million population) and Osaka (2.5 million population). Seven sampling sites were selected along the Yodo river system. In October 2017, 1 L surface water was sampled from the center of the river using a water sampler. Bottom sediments were also collected in five sites using a grab sampler for analyses of heavy metals. 

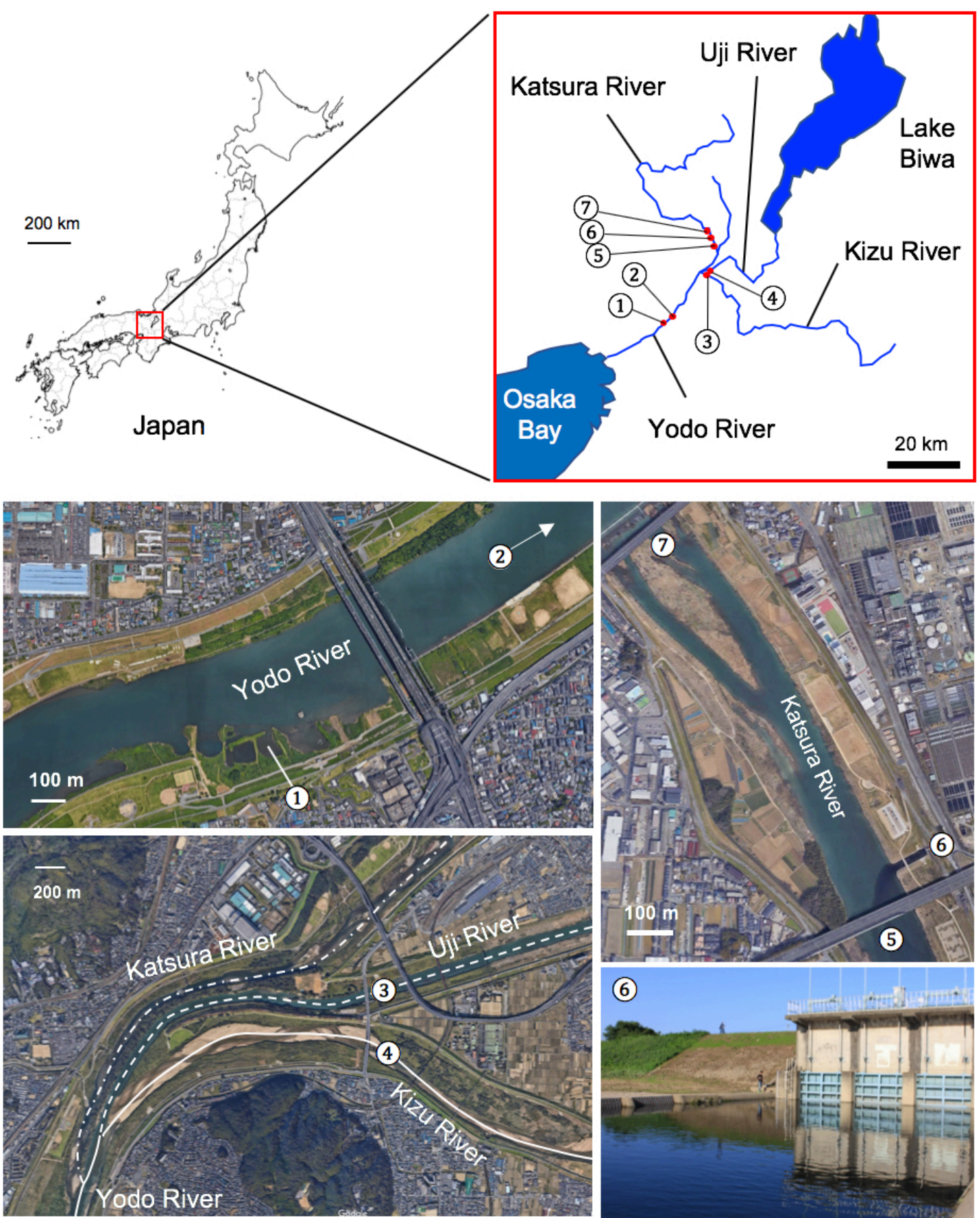

Figure 1 Map of sampling sites. (1) Niwakubo Wando (Yodo River), (2) Hirakata Bridge (Yodo River), (3) Goko Bridge (Kizu River), (4) Goko Bridge (Uji River), (5) Miyamae Bridge (Katsura River), (6) Toba STP (Katsura River), (7) Kuzu Bridge (Katsura River). Site (6) is an inflow point of treated water from a Sewage Treatment Plant. Site (1) is a stagnant water area formed by an artificial bank constructed from the side of the river. 
http://wjst.wu.ac.th

\section{Water quality measurements}

Water temperature was measured at the sampling sites. The $\mathrm{pH}$ was measured using a $\mathrm{pH}$ meter F51 (Horiba, Japan), and electrical conductivity (EC) was determined using an EC meter (CM-25R, Toa, Japan). The chemical oxygen demand (COD) was measured using the $\mathrm{KMnO}_{4}$ titration method. Water alkalinity was measured by a titration method using $0.01 \mathrm{~mol} / \mathrm{L} \mathrm{H}_{2} \mathrm{SO}_{4}$. Nitrate content $\left(\mathrm{NO}_{3}{ }^{-} \mathrm{N}\right)$ was measured using a Flow Injection Analyzer (FIA, OG1S-300S). Suspended solids (SS) were measured by filtration with a $1 \mu \mathrm{m}$ filter. For heavy metals analyses, samples were treated with $\mathrm{HNO}_{3}$, and concentrations of $\mathrm{Cu}, \mathrm{Zn}, \mathrm{Cd}$, and $\mathrm{Pb}$ were measured using a heavy metal analyzer (ICPS-7510), while that of $\mathrm{Hg}$ was determined using a mercury analyzer (HG-320 J).

\section{DNA extraction and quantification}

A $100 \mathrm{~mL}$ water sample was vacuum filtered with a $0.2 \mu \mathrm{m}$ pore size polycarbonate membrane filter (Advantec, Mfs., Inc. Japan). DNA was extracted from the filter using a PowerWater DNA isolation kit (MO BIO Laboratories, Inc.) according to the manufacturer's protocol. The DNA concentration was quantified using a Qubit 2.0 Fluorometer (Invitrogen).

\section{PCR-RFLP}

The 16S ribosomal RNA (rRNA) and 18S rRNA regions were amplified with the extracted DNA using Emerald Amp PCR Master mix (TaKaRa Bio) with universal primers (Table 1; [17,18]) and T100 Thermal Cycler (Bio-Rad). The amplification steps included initial denaturation at $95{ }^{\circ} \mathrm{C}$ for 2 min (Step 1), then $95{ }^{\circ} \mathrm{C}$ for $30 \mathrm{~s}$ (Step 2), annealing at $52^{\circ} \mathrm{C}$ for $30 \mathrm{~s}$ (Step 3), extension at $72{ }^{\circ} \mathrm{C}$ for $100 \mathrm{~s}$ (Step 4), and 34 cyclings from Step 2 to 4 , with a final extension step at $72{ }^{\circ} \mathrm{C}$ for $5 \mathrm{~min}$ (Step 5).

The PCR product $(7 \mu \mathrm{L})$ was then digested with $0.5 \mu \mathrm{L}$ restriction enzyme $(10 \mathrm{U} / \mu \mathrm{L})$ of EcoRV, ApaI, XhoI, DraI, HinfI, or FokI (Promega), with $1 \mu \mathrm{L}$ of $10 \times$ buffer and $0.1 \mu \mathrm{L}$ of bovine serum albumin $(10 \mu \mathrm{g} / \mu \mathrm{L})$, for $2 \mathrm{~h}, 37^{\circ} \mathrm{C}$. Restriction fragments were separated on $1.5 \%$ agarose gel in TAE buffer for $30 \mathrm{~min}, 100 \mathrm{~V}$, and stained with ethidium bromide for visualization under a UV illuminator. Along the length of the electrophoresis gel, the presence or absence of restriction fragments was scored. The fluorescent intensity of each fragment was also scored by $1=$ weak, $2=$ normal, $3=$ strong.

The three restriction fragments that were specific to some sampling sites were excised from agarose gel, purified using Nucleospin Gel and PCR Clean-up (TaKaRa, Japan), and sequenced. The sequences were compared with the NCBI Genbank database (May 2019) using the BLASTN program to identify plausible species.

\section{Data analysis}

Correlation analysis was performed by computing Pearson's correlation coefficient $(r)$. PCA was performed from the scoring data of PCR-RFLP banding patterns for dimensional reduction, and four major principal components (PCs) were computed. The four PCs, integrating the information of RFLP banding pattern, total number of bands, and DNA concentration, were used as parameters of microbial DNA analyses. These parameters were then combined with the water quality parameters, and a second PCA was performed to analyze correlations of molecular biological and water chemical parameters. All statistical analyses were performed using the JMP software ver. 10 (SAS Institute).

Table 1 Universal primers for 16S rRNA (Bacteria) and 18S rRNA (Eukaryote)

\begin{tabular}{|c|c|c|}
\hline Target Region & Primer Name & Sequence $\left(5^{\prime}\right.$ to $\left.3^{\prime}\right)$ \\
\hline \multirow{2}{*}{$16 S r R N A$} & 16S_UNIV_27F & AGAGTTTGATCCTGGCTCAG \\
\hline & 16S_UNIV_1492R & GGCTACCTTGTTACGACTT \\
\hline \multirow{2}{*}{$18 S \mathrm{rRNA}$} & 18S_EukF1 & ACCTGGTTGATCCTGCCAG \\
\hline & 18S_EukR1 & TGATCCTTCYGCAGGTTCAC \\
\hline
\end{tabular}


http://wjst.wu.ac.th

Table 2 Water quality measurements in the seven sampling sites along the Yodo river system in Japan. Samples were collected in October 2017. The highest values are shown in bold

\begin{tabular}{lllllllll}
\hline Sampling site & & $\mathbf{1}$ & $\mathbf{2}$ & $\mathbf{3}$ & $\mathbf{4}$ & $\mathbf{5}$ & $\mathbf{6}$ & $\mathbf{7}$ \\
\hline $\mathrm{Temp}\left({ }^{\circ} \mathrm{C}\right)$ & & 16 & 16 & 19 & 17 & 17 & $\mathbf{2 1}$ & 16 \\
$\mathrm{pH}$ & & 6.6 & 6.5 & 6.7 & 6.3 & 6.9 & $\mathbf{7 . 3}$ & 6.8 \\
$\mathrm{EC}(\mathrm{mS} / \mathrm{m})$ & & 10.3 & 10.3 & 13.4 & 8.3 & 11.7 & $\mathbf{3 1 . 4}$ & 6.9 \\
$\mathrm{COD}\left(\mathrm{mgO}_{2} / \mathrm{L}\right)$ & & - & 5.0 & 4.6 & 5.1 & 5.3 & $\mathbf{1 3 . 7}$ & 3.3 \\
$\mathrm{Alkalinity}(\mathrm{mg} / \mathrm{L})$ & $\mathrm{pH} 4.8$ & 0.41 & 0.39 & 0.52 & 0.15 & 0.41 & $\mathbf{0 . 8 5}$ & 0.34 \\
& $\mathrm{pH} 4.3$ & 0.46 & 0.44 & 0.57 & 0.34 & 0.45 & $\mathbf{0 . 9 5}$ & 0.42 \\
$\mathrm{NO}_{3} \mathrm{~N}(\mathrm{mg} / \mathrm{L})$ & & 0.5 & 0.5 & 0.3 & 0.8 & 0.8 & $\mathbf{3 . 5}$ & 0.4 \\
$\mathrm{SS}(\mathrm{mg} / \mathrm{L})$ & & 50.3 & 56.9 & 42.4 & 65.7 & 78.8 & 13.5 & $\mathbf{9 5 . 4}$ \\
$\mathrm{Hg}(\mathrm{ppm})$ & Water $(\mathrm{mg} / \mathrm{L})$ & $\mathrm{ND}$ & $\mathrm{ND}$ & $\mathrm{ND}$ & $\mathrm{ND}$ & $\mathrm{ND}$ & $\mathrm{ND}$ & $\mathrm{ND}$ \\
$\mathrm{Cu}(\mathrm{ppm})$ & Water $(\mathrm{mg} / \mathrm{L})$ & 0.006 & 0.011 & 0.013 & 0.008 & 0.012 & $\mathbf{0 . 0 1 7}$ & $\mathbf{0 . 0 1 7}$ \\
& $\mathrm{BS}(\mu \mathrm{g} / \mathrm{g})$ & 4.545 & 1.158 & 16.323 & 9.056 & $\mathbf{1 9 . 3 5 4}$ & - & - \\
$\mathrm{Zn}(\mathrm{ppm})$ & Water $(\mathrm{mg} / \mathrm{L})$ & 0.014 & 0.015 & 0.013 & 0.014 & 0.019 & $\mathbf{0 . 0 3 1}$ & 0.014 \\
& $\mathrm{BS}(\mu \mathrm{g} / \mathrm{g})$ & 40.862 & 31.317 & 12.212 & 35.504 & $\mathbf{8 6 . 5 9 6}$ & - & - \\
$\mathrm{Cd}(\mathrm{ppm})$ & Water $(\mathrm{mg} / \mathrm{L})$ & $\mathrm{ND}$ & $\mathrm{ND}$ & $\mathrm{ND}$ & $\mathrm{ND}$ & $\mathrm{ND}$ & $\mathrm{ND}$ & $\mathrm{ND}$ \\
& $\mathrm{BS}(\mu \mathrm{g} / \mathrm{g})$ & $\mathrm{ND}$ & $\mathrm{ND}$ & $\mathrm{ND}$ & $\mathrm{ND}$ & $\mathrm{ND}$ & $\mathrm{ND}$ & $\mathrm{ND}$ \\
$\mathrm{Pb}(\mathrm{ppm})$ & Water $(\mathrm{mg} / \mathrm{L})$ & 0.004 & 0.006 & 0.005 & 0.004 & $\mathbf{0 . 0 0 8}$ & 0.002 & 0.007 \\
& $\mathrm{BS}(\mu \mathrm{g} / \mathrm{g})$ & 0.021 & 0.333 & 12.192 & 9.136 & $\mathbf{2 1 . 6 4 0}$ & - & - \\
\hline $\mathrm{ND}=\mathrm{Not}$ & & & &
\end{tabular}

$\mathrm{ND}=$ Not Detected $<$ Detection Limit $(\mathrm{ppm}): \mathrm{Hg}=0.0001, \mathrm{Cu}=0.001, \mathrm{Zn}=0.001, \mathrm{Cd}=0.0003, \mathrm{~Pb}=$ 0.001; BS = Bottom Sediment; - = Missing data. (1) Niwakubo Wando (Yodo River), (2) Hirakata Bridge (Yodo River), (3) Goko Bridge (Kizu River), (4) Goko Bridge (Uji River), 5 Miyamae Bridge (Katsura River), (6) Toba STP (Katsura River), (7) Kuzu Bridge (Katsura River).

\section{Results and discussion}

\section{Water quality}

Table 2 shows the results of water quality measurements at seven sampling sites along the Yodo river system in Japan. Sampling site (6), the inflow point of the sewage treatment plant, shows a different profile from other sites: Water temperature, $\mathrm{pH}, \mathrm{EC}, \mathrm{COD}$, Alkalinity, and $\mathrm{NO}_{3}{ }^{-}-\mathrm{N}$ in site (6) were higher than other sites, whereas SS was the smallest in site (6). Sewage from the residential areas, containing organic and inorganic pollutants, alters the physicochemical parameters of freshwater, such as $\mathrm{pH}$, temperature, dissolved oxygen content, and COD, which greatly affects the microbial community structure [19].

Heavy metal concentrations in surface water were generally low $(<0.01 \mathrm{ppm})$, indicating no serious pollution in the river system. We also measured the heavy metal concentrations of bottom sediments in the first five sites and found much higher concentrations than those of surface water. Heavy metal concentrations in bottom sediments tended to be correlated with those in surface water: $\mathrm{Cu}, r=0.59(p=$ $0.30) ; \mathrm{Zn}, r=0.95(p<0.05) ; \mathrm{Pb}, r=0.55(p=0.34)$. Site (5), Miyamae bridge on the Katsura river, showed higher concentrations of heavy metals than the other sites. Benthic invertebrate assemblages are often used to quantify the ecological condition of aquatic ecosystems and water quality [10,11]. Because of higher heavy metal concentrations in bottom sediments than surface water, the DNA-based analysis of the benthic organismal community in bottom sediment is also important to assess the potential risk of pollution and to identify bioindicators of ecosystem degradation in river systems [20,21]. 
16SrRNA
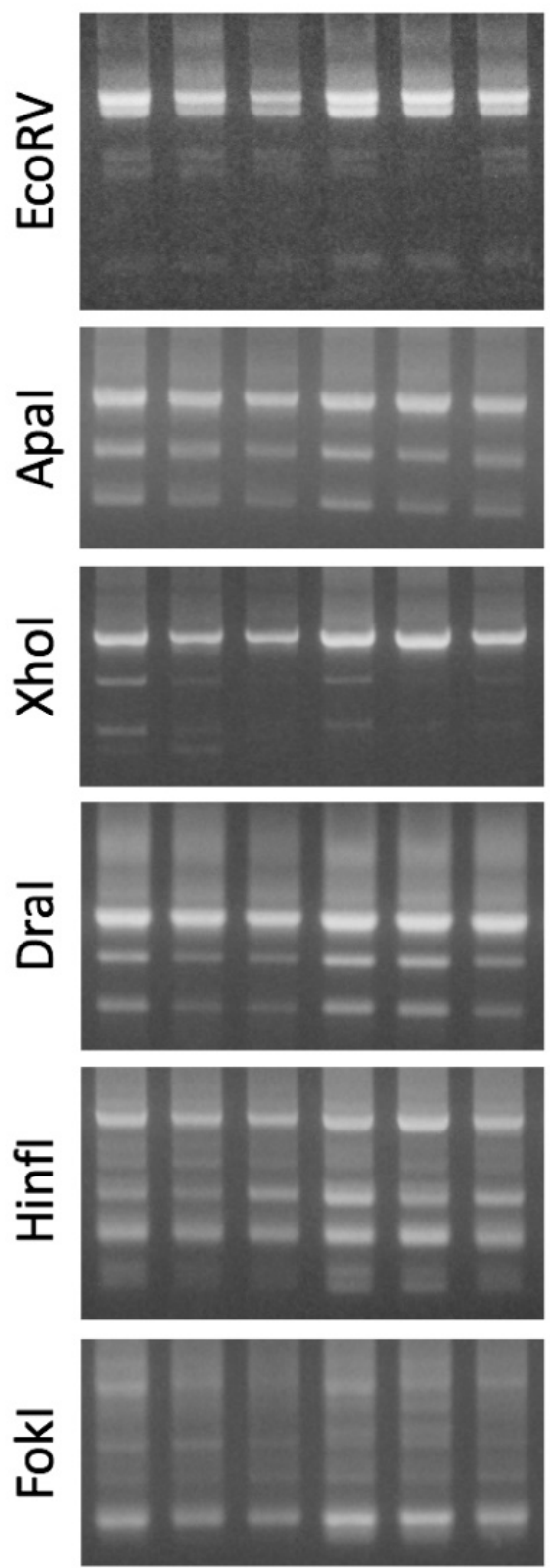

(1) (2) (4) (5) (6) 7


Figure 2 PCR-RFLP on agarose gels for microbial DNAs in water sampled in seven sites along the Yodo river system in Japan. $1.5 \%$ agarose gels were used for separations. Six restriction enzymes are shown on the left. (1) Niwakubo Wando (Yodo River), (2) Hirakata Bridge (Yodo River), (4) Goko Bridge (Uji River), (5) Miyamae Bridge (Katsura River), (6) Toba STP (Katsura River), (7) Kuzu Bridge (Katsura River). (6) is an inflow point of treated water from the Toba Sewage Treatment Plant. 


\section{PCR-RFLP}

Figure 2 shows the PCR-RFLP banding pattern across six sampling sites, and Table 3 summarizes the polymorphic information of restriction enzymes used. Each enzyme produces three to twelve visible bands on the agarose gel. Restrictions by the three enzymes XhoI, HinfI, and FokI resulted in higher levels of polymorphism in the presence/absence of bands among the study sites (Table 3), indicating that these enzymes are useful for analyses of microbial genetic diversity. In contrast, EcoRV, ApaI, and DraI restriction fragments of $16 \mathrm{~S}$ rRNA did not show any polymorphisms in the presence/absence of bands among sites. Although our data resulted from only a few sampling sites in a river system, the results indicated potentially informative enzymes that can distinguish microorganismal diversity in freshwater environments.

Sequencing analyses of three bands specific to some sampling sites successfully identified plausible species (Table 4). A restriction fragment of $18 \mathrm{~S}$ rRNA by the enzyme ApaI was specific to site (5) (Miyamae bridge at Katsura river), and its nucleotide sequence was close to a protozoan of Chyrophyceae isolated in a Japanese river [22], indicating that similar species inhabit the Katsura river. Some restriction fragments of 18S rRNA by the FokI enzyme were specific to sites (1) and (6), and the sequence was close to a ciliate (Glaucoma scintillans) isolated in wastewater treatment plants [23]. The ciliate is a common protozoan in sewage and can be contaminated in the inflow of site (6). Site (1) (Niwakubo wando) is an artificial pond directly connected to the Yodo river, and both sites (1) and (6) had stagnant water, while other sites had fast-flowing water in the center of the river. Stagnant water environments may be favored by the ciliate. The third sequence sample, collected from the restriction fragment of $18 \mathrm{~S}$ rRNA by the enzyme HinfI, which was specific to sites (4) and (7), shows a close nucleotide sequence with an environmental DNA sample collected in a mesotrophic lake in Japan [24].

Table 5 summarizes microbial DNA analyses. The DNA concentration in surface water was the highest in site (6), an inflow site of the sewage treatment plant, which may be the best site for microbes in terms of relatively high temperature, high nutrients, and high organic contents indicated by $\mathrm{EC}$ and $\mathrm{NO}_{3}{ }^{-}$ N (Table 2). The total number of bands, an indicator of microbial genetic diversity, was the highest in site (1) (Niwakubo wando), where stagnant water environments may allow diverse microbes to thrive, such as protozoa and phytoplankton species. PCA integrates the RFLP banding pattern into four PCs (Table 5): the $\mathrm{RFLP}^{\mathrm{PC} 1}$ corresponded to $39.3 \%$ of the total variance and was the highest in site (6), while the second RFLP $^{\mathrm{PC} 2}$ integrated $21.8 \%$ of the total variance and was the highest in site (1). The third RFLP ${ }^{\mathrm{PC} 3}$ and fourth RFLP ${ }^{\mathrm{PC} 4}$ contained 16.8 and $14.2 \%$ variance and were the highest and lowest in site (7), respectively. The RFLP PCs showed no clear clustering or correlation among the six sites, indicating a high diversity of banding patterns.

The major disadvantage of the PCR-RFLP approach is its limited ability to distinguish the diversity of DNA sequences, and potentially informative variation in DNA sequences may be cryptic to the method [16]. However, our PCR-RFLP approach with multiple enzymes showed a high level of polymorphism, especially in 18S rRNA (Table 3), and identified a part of microbiome diversity in a river system (Table 5). The resolution of genotyping can be enhanced by increasing the restriction enzymes used and using a high-resolution, denaturing gradient gel electrophoresis [25].

\section{Water quality $\&$ microbiomes}

To evaluate the potential usefulness of microbial DNA analyses as water quality assessments, we performed a second PCA based on the correlations between the seven parameters of microbial DNA analyses (Table 5) and 10 parameters of water quality (Table 2, excluding temperature, COD with a missing data, and heavy metals in bottom sediments). 
http://wjst.wu.ac.th

Table 3 Polymorphism of six restriction enzymes used for PCR-RFLP in $1.5 \%$ agarose gels

\begin{tabular}{lllll}
\hline \multirow{2}{*}{ Restriction enzyme } & \multicolumn{2}{c}{ 16S rRNA } & \multicolumn{1}{c}{ 18S rRNA $^{$\cline { 2 - 5 }$}$} \\
\cline { 2 - 5 } & No. of bands $^{\dagger}$ & \% Polymorphism & No. of bands & \% Polymorphism $^{\S}$ \\
\hline EcoRV & 5 & $\mathbf{0}(40)$ & 4 & $75(75)$ \\
ApaI & 3 & $\mathbf{0}(33)$ & 3 & $67(67)$ \\
XhoI & 4 & $75(100)$ & 5 & $80(80)$ \\
DraI & 3 & $\mathbf{0}(67)$ & 4 & $25(100)$ \\
HinfI & 7 & $57(100)$ & 12 & $83(100)$ \\
FokI & 7 & $100(100)$ & 5 & $80(100)$ \\
\hline
\end{tabular}

$\dagger$, The total number of different-sized bands separated in $1.5 \%$ agarose gels (See Figure 2 for gel images).

$\S$, Percentage of polymorphic bands based on presence/absence of the band for six samples. Percentages of polymorphic bands based on the score of band intensity are also shown in parentheses.

Table 4 Sequencing of PCR-RFLP fragments amplified from microbial DNAs

\begin{tabular}{lllllll}
\hline $\begin{array}{l}\text { Target } \\
\text { Region }\end{array}$ & Enzyme & $\begin{array}{l}\text { Length } \\
\text { (bp) }\end{array}$ & $\begin{array}{l}\text { Sampling } \\
\text { Site }\end{array}$ & \multicolumn{3}{c}{ Top hit by BLASTN on NCBI database } \\
Identity (\%) & Genbank ID & Organism \\
\hline $18 S$ rRNA & ApaI & 900 & 5 & 99.7 & AB749110 & Chrysophyceae \\
$18 S$ rRNA & FokI & 1,462 & 1 (16) & 98.8 & AJ511861 & Glaucoma scintillans \\
$18 S r R N A$ & HinfI & 324 & (4) 7 & 99.4 & AB622330 & Freshwater eukaryote \\
\hline
\end{tabular}

Table 5 Summary of molecular biological analyses of microbial DNAs extracted from surface water in six sampling sites along the Yodo river system in Japan

\begin{tabular}{|c|c|c|c|c|c|c|c|c|}
\hline \multicolumn{3}{|c|}{ Sampling site } & (1) & (2) & (4) & (5) & (6) & (7) \\
\hline \multicolumn{3}{|c|}{ DNA concentration $(\mu \mathrm{g} / \mathrm{L})$} & 1.18 & 2.08 & 1.98 & 2.58 & 4.70 & 0.88 \\
\hline \multirow{2}{*}{\multicolumn{2}{|c|}{ No. of bands ${ }^{\dagger}$}} & 16S rRNA & 25 & 21 & 18 & 22 & 22 & 23 \\
\hline & & $18 \mathrm{~S}$ rRNA & 23 & 19 & 15 & 21 & 16 & 19 \\
\hline \multicolumn{9}{|c|}{ PCA of RFLP banding pattern ${ }^{\S}$} \\
\hline $\mathrm{RFLP}^{\mathrm{PC}}$ & Eigenvalues & $\begin{array}{l}\text { \% Variance } \\
\text { explained }\end{array}$ & (1) & (2) & (4) & (5) & (6) & (7) \\
\hline $\mathrm{RFLP}^{\mathrm{PC} 1}$ & 20.8 & 39.3 & -2.89 & -5.13 & -2.49 & 4.82 & 6.31 & -0.61 \\
\hline $\mathrm{RFLP}^{\mathrm{PC} 2}$ & 11.6 & 21.8 & 4.36 & -0.60 & -4.29 & 3.46 & -2.83 & -0.11 \\
\hline RFLP $^{\mathrm{PC} 3}$ & 8.9 & 16.8 & 2.45 & -3.30 & -0.66 & -3.42 & 1.16 & 3.77 \\
\hline RFLP $^{\mathrm{PC} 4}$ & 7.5 & 14.2 & 2.47 & 1.54 & -1.47 & -2.21 & 3.15 & -3.48 \\
\hline
\end{tabular}

$\dagger$, Total number of visible bands in $1.5 \%$ agarose gels generated by PCR-RFLP with six restriction enzymes (See Figure 2 for gel images).

§, Principal component analysis was performed using the PCR-RFLP banding patterns for dimensional reduction. Four principal components ( $\left.{ }^{\mathrm{RFLP}} \mathrm{PCs}\right)$ are shown with their eigenvalues and percentage variance explained. 

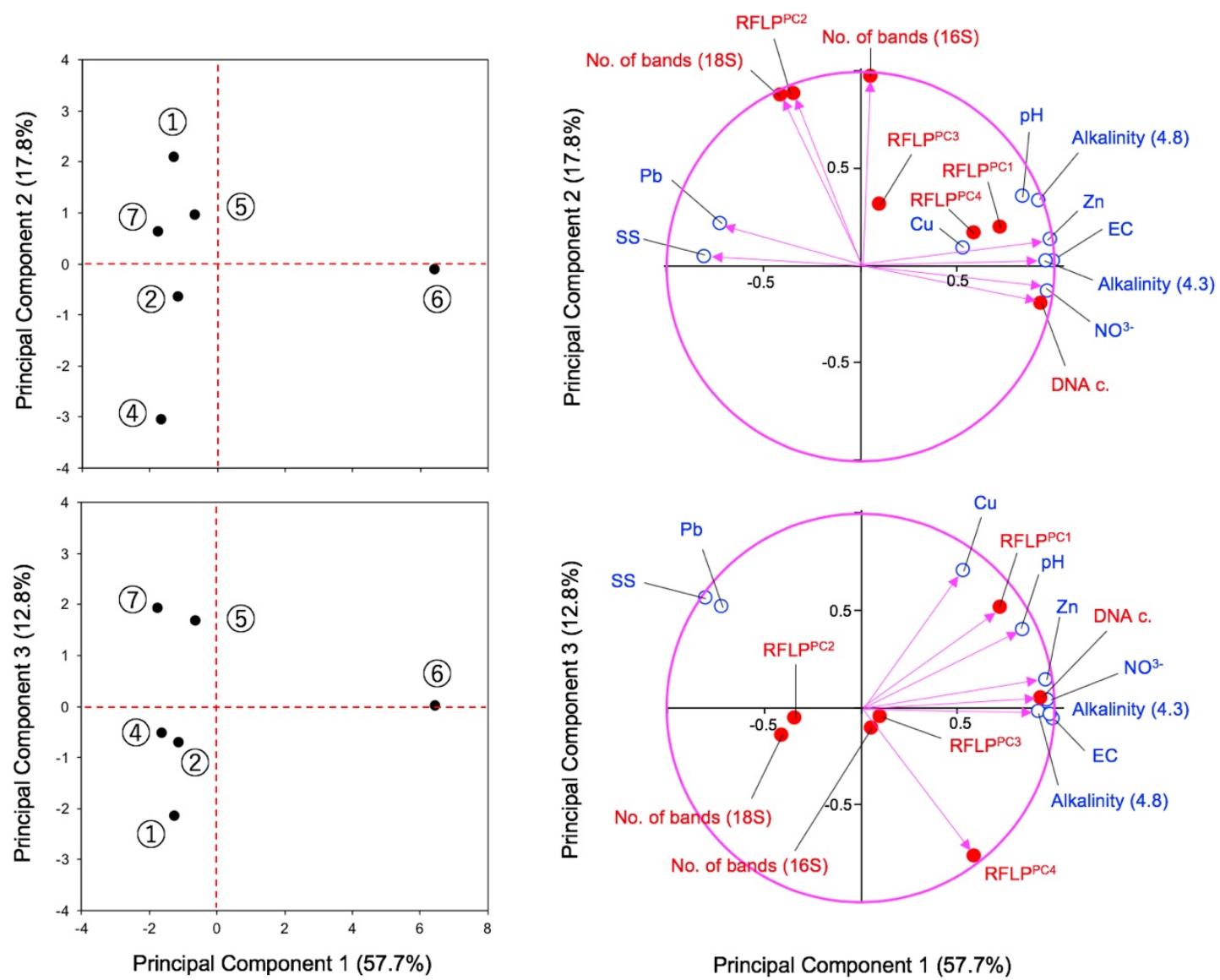

Figure 3 Principal component analysis of water quality parameters and microbial DNA parameters measured at six sites in the Yodo river system, Japan. Left figures are scatter plots of three principal components: (1) Niwakubo Wando (Yodo River), (2) Hirakata Bridge (Yodo River), (4) Goko Bridge (Uji River), (5) Miyamae Bridge (Katsura River), (6) Toba STP (Katsura River), (7) Kuzu Bridge (Katsura River). Right figures show scatter plots of principal component loadings of each parameter.

The second PCA of the 17 parameters among six sites resulted in the first PC of $57.7 \%$ variance explained (Figure 3). Along the first PC, site (6) was well separated from the other sites. Loading plots show that the first PC was negatively correlated with the concentrations of $\mathrm{Pb}$ and SS and positively correlated with other water parameters. As mentioned earlier in the section on water quality, site (6) had different water quality parameters than the other sites (Table 2), and the PCA visualized the data structure well. The microbial DNA concentration (DNA c.), RFLP $^{\mathrm{PCl}}$, and $\mathrm{RFLP}^{\mathrm{PC} 4}$ were also integrated into the first PC (Figure 3), indicating that these microbial DNA parameters represented microbiome changes associated with the changes in water quality parameters. The inflow from sewage treatment plants in the river may induce eutrophic environments and result in the dominance of fast-growing microorganisms. In addition, sewage may also introduce microbiological contamination to the river [26]. The fragment with a close nucleotide sequence to ciliate (Table 5) could be a bioindicator of inflow contamination from sewage.

Interestingly, the second $\mathrm{PC}$, with a $17.8 \%$ variance, consisted of the factors of RFLP ${ }^{\mathrm{PC} 2}$, number of bands, and RFLP ${ }^{\mathrm{PC} 3}$ (Figure 3), and was not correlated with any water parameters measured. Therefore, these parameters of microbial DNA analyses represent microbiome changes independent of water quality 
http://wjst.wu.ac.th

data measured in this study. Because site (1) had the highest value of second PC (Figure 3), its stagnant water environment may form a different microbial community than the other water-floating environments. Other topographic, hydrological, and geological factors, such as water flow rate, water depth, and connection to Lake Biwa, might also be potential factors shaping the microbiome changes represented by the second PC. Furthermore, the third PC with $12.8 \%$ variance visualized the cluster of loading vectors of $\mathrm{Cu}, \mathrm{pH}$, and RFLP ${ }^{\mathrm{PC} 1}$ and separated the RFLP ${ }^{\mathrm{PC} 4}$ from other water parameters (Figure 3). This indicates that $\mathrm{RFLP}^{\mathrm{PC} 1}$ had close relationships with $\mathrm{Cu}$ and $\mathrm{pH}$, and $\mathrm{RFLP}^{\mathrm{PC} 4}$ is another axis of variance independent of water quality parameters, although the \% variance explained is low $(12.8 \%)$.

The PCR-RFLP analyses of 16S rRNA have successfully detected changes in bacterial community diversity in response to the heavy metal pollutions in a Chinese river [27] and the contamination of livestock wastewater in groundwater [28]. The PCR-based cloning approach analyzing microbial community structure in water samples in a Chinese copper mine identified significant associations of microbial community composition and water environmental variables, such as $\mathrm{pH}$, iron, sulfur, and calcium concentrations [29]. Thus, previous studies have demonstrated the usefulness of the PCR-RFLP method to detect microbial community changes in response to water environmental pollution. We found a sign of microbial community changes possibly associated with the input of treated sewage water in the Yodo river system in Japan. We also suggest that the PCR-RFLP analysis of microbial DNA can detect microbiome changes that are independent of the changes in chemical water quality, implying that the microbial DNA analysis can characterize additional aspects of water environments (such as topographic, hydrological, or geological aspects) that are not represented by the chemical parameters of water quality.

\section{Conclusions}

The present study shows water environmental assessment based on water chemistry and microbiomes in a metropolitan river system in Japan. The results demonstrate that a simple molecular analysis (PCR-RFLP) can sensitively detect at least a part of the microbiome changes. The PCA suggests that the microbiome changes detected by PCR-RFLP are associated with water quality changes caused by the input of treated sewage water, indicating that the method has the potential for developing bioindicators of environmental pollution. Further sequencing analyses of restriction fragments are required to make a list of microbial species as a potential indicator of water environmental changes in the river system. Currently, a high-throughput sequencer can produce massive sequence data of microbiomes from environmental samples, and the cost is decreasing rapidly. This technical development will further promote microbiome analyses as a direct detector of pathogenic microbes and as sensitive indicators of ecosystem degradation and environmental pollution.

\section{Acknowledgments}

The authors would like to express our deep gratitude to the management of the Osaka Institute of Technology (OIT), and the Director of the Department of Environmental Engineering, OIT, Osaka, Japan, for full use of their facilities during the planning and developing of this research. The authors would also like to thank the Directorate of Higher Education, Ministry of Research, Technology, and Higher Education, of the Republic of Indonesia for supported funding through a Short Course on Molecular Biology.

\section{References}

[1] S Suthar, J Sharma, M Chabukdhara and AK Nema. Water quality assessment of river Hindon at Ghaziabad, India: impact of industrial and urban wastewater. Environ. Monit. Assess 2010; 165, 103-12.

[2] J Rousk and P Bengtson. Microbial regulation of global biogeochemical cycles. Front. Microbiol. 2014; 5, 103.

[3] LH Zeglin. Stream microbial diversity in response to environmental changes: Review and synthesis of existing research. Front. Microbiol. 2015; 6, 454. 
http://wjst.wu.ac.th

[4] Y Bai, W Qi, J Liang and J Qu. Using high-throughput sequencing to assess the impacts of treated and untreated wastewater discharge on prokaryotic communities in an urban river. Appl. Environ. Microbiol. 2014; 98, 1841-51.

[5] A Lapanje, D Drobne, S Nikcevic, A Perović, P Zidar, J Štrus, H Hollert and G Karaman. Bacterial community Structure analyses to assess pollution of water and sediments in the lake shkodra/skadar, Balkan Peninsula. Environ. Sci. Pollut. Res. Int. 2005; 12, 361-8.

[6] S Tiquia. Metabolic diversity of the heterotrophic microorganisms and potential link to pollution of the Rouge River. J. Environ. Pollut. 2010; 158, 1435-43.

[7] L Wang, J Zhang, H Li, H Yang, C Peng, Z Peng an L Lu. Shift in the microbial community composition of surface water and sediment along an urban river. Sci. Total Environ. 2018; 627, 60012.

[8] K Jordaan and C Bezuidenhout. Bacterial community composition of an urban river in the North West Province, South Africa, in relation to physico-chemical water quality. Environ. Sci. Pollut. Res. Int. 2016; 23, 5868-80.

[9] Y Pei, Z Yu, J Ji, A Khan and X Li. Microbial community structure and function indicate the severity of chromium contamination of the Yellow River. Front. Microbiol. 2018; 9, 38.

[10] JC Morse, YJ Bae and G Munkhjargal, N Sangpradub, K Tanida, TS Vshivkova, B Wang, LYang and CM Yule. Freshwater biomonitoring with macroinvertebrates in East Asia. Fornt. Ecol. Environ. 2007; 5, 33-42.

[11] VH Resh and DM Rosenberg. Freshwater biomonitoring and benthic macroinvertebrates. Chapman \& Hall, New York, 1993.

[12] RO Carey, GJ Hochmuth, CJ Martinez, TH Boyer, MD Dukes, GS Toor and JL Cisar. Evaluating nutrient impacts in urban watersheds: Challenges and research opportunities. Environ. Pollut. 2013; 173, 138-49.

[13] N Zheng, Q Wang, Z Liang and D Zheng. Characterization of heavy metal concentrations in the sediments of three freshwater rivers in Huludao City, Northeast China. J. Environ. Pollut. 2008; 154, 135-42.

[14] L Zinger, A Gobet and T Pommier. Two decades of describing the unseen majority of aquatic microbial diversity. Mol. Ecol. 2012; 21, 1878-96.

[15] M Pfrender, C Hawkins, M Bagley, G Courtney, B Creutzburg, JH Epler, S Fend, D Schindel, LCJ Ferrington, PL Hartzell, S Jackson, DP Larsen, A Lévesque, JC Morse, MJ Petersen, D Ruiter and M Whiting. Assessing macroinvertebrate biodiversity in freshwater ecosystems: Advances and challenges in DNA-based approaches. Quart. Rev. Biol. 2010; 85, 319-40.

[16] $\mathrm{J}$ Theron and $\mathrm{T}$ Cloete. Molecular techniques for determining microbial diversity and community structure in natural environments. Crit. Rev. Microbiol. 2000; 26, 37-57.

[17] SYS der Moon G G Grin der Staay, L Guillou, D Vaulot, H Claustre and LK Medlin. Abundance and diversity of prymnesiophytes in the picoplankton coumunity from the equatorial pacific ocean inferred from 18S rDNA sequences. Limnol. Oceanogr. 2000; 45, 98-109.

[18] WG Weisburg, SM Barns, DA Pelletier and DJ Lane. 16S ribosomal DNA amplification for phylogenetic study. J. Bacteriol. 1991; 173, 697-703.

[19] T García-Armisen, Ö İnceoğlu, NK Ouattara, A Anzil, MA Verbanck, N Brion and P Servais. Seasonal variations and resilience of bacterial communities in a sewage polluted urban river. PLoS One 2014. 9, e92579.

[20] W Sun, T Xiao, M Sun, Y Dong, Z Ning, E Xiao, S Tang and J Li. Diversity of the sediment microbial community in the Aha watershed (Southwest China) in response to acid mine drainage pollution gradients. Appl. Environ. Microbiol. 2015; 81, 4874-84.

[21] H Yin, J Niu, Y Ren, J Cong, X Zhang, F Fan, Y Xiao, X Zhang, J Deng, M Xie, Z He, J Zhou, Y Liang and $\mathrm{X}$ Liu. An integrated insight into the response of sedimentary microbial communities to heavy metal contamination. Sci. Rep. 2015; 5, 14266.

[22] K Nakamura and M Suto. Analysis of bacterivorous protozoa in the natural environment (in Japanese). J. Jap. Soc. Civil Eng. Ser. G 2012; 68, III_31-III_40. 
[23] J Fried, W Ludwig, R Psenner and KH Schleifer. Improvement of ciliate identification and quantification: A new protocol for fluorescence in situ hybridization (FISH) in combination with silver stain techniques. Syst. Appl. Microbiol. 2002; 25, 555-71.

[24] N Fujimoto, E Matsuo and M Murata. Evaluation of the small-eukaryote community composition in a mesotrophic lake by sequencing the 18S rRNA genes. Jap. J. Water Treat Biol. 2014; 50, 85-94.

[25] H Sekiguchi, M Watanabe, T Nakahara, B Xu and H Uchiyama. Succession of bacterial community structure along the Changjiang River determined by denaturing gradient gel electrophoresis and clone library analysis. Appl. Environ. Microbiol. 2002; 68, 5142-50.

[26] B Drury, E Rosi-Marshall and JJ Kelly. Wastewater treatment effluent reduces the abundance and diversity of benthic bacterial communities in urban and suburban rivers. Appl. Environ. Microbiol. 2013; 79, 1897-905.

[27] J Zhu, J Zhang, Q Li, T Han, J Xie, Y Hu and L Chai. Phylogenetic analysis of bacterial community composition in sediment contaminated with multiple heavy metals from the Xiangjiang River in China. Mar. Pollut. Bull. 2013; 70, 134-9.

[28] JC Cho and SJ Kim. Increase in bacterial community diversity in subsurface aquifers receiving livestock wastewater input. Appl. Environ. Microbiol. 2000; 66, 956-65.

[29] H Yin, G Qiu, L Wu, M Xie, J Zhou, Z Dai, D Wang, L Kellogg, L Cao and X Liu. Microbial community diversity and changes associated with a mine drainage gradient at the Dexing copper mine, China. Aquat. Microb. Ecol. 2008; 51, 67-76. 